\title{
THE CHURCH OF ST. MAGNUS AND THE BOOKSELLERS OF LONDON BRIDGE.
}

\begin{abstract}
HE value of our old church books as historical records has never been, and is not yet, properly recognised. By church books, I mean the churchwardens' books of accounts, vestry minutes, overseers' and other books of a miscellaneous character, which form the records of every parish throughout the kingdom.

To the clerical and lay mind alike, there is only one set of records worth preserving in the parish chest, and that is the parish registers of baptisms, marriages and burials. This is a very grave mistake which in the past has led to the wholesale destruction of valuable records, and which is still responsible for the indifference shewn by so many of our clergy and churchwardens to any books but the parish registers, and for the failure of any sort of system for the preservation or arrangement of these other books, where they still exist.

Invaluable as parish registers must always be, they do not tell us anything about the life of the parish, who were the most influential men in it, and what part they played in its history. They do not tell us anything about the events that brought joy or sorrow to the parishioners, what
\end{abstract}


THE CHURCH OF ST. MAGNUS. 385

set the bells ringing or the bonfires blazing; nor do they shew us how money was raised by the overseers, who paid it, how it was spent, or who benefited by it. For these and many other details of civic life you must go to the churchwardens' books and other parish records mentioned above.

Those who are interested in the history of London have cause to rejoice at the public spirit of the late Deputy White, who exerted himself with wonderful success to induce the clergy of the churches within the city of London to deposit their old church records, other than the registers, in the Guildhall Library.

Amongst those who fell in with Deputy White's scheme were the vicar and churchwardens of St. Magnus the Martyr, in Thames Street. The present church, though standing on exactly the same site as the church of the same name destroyed in 1666 , is some distance to the east of London Bridge, whereas the old building stood right up against the north-east corner of Old London Bridge, the explanation of this being that the new bridge was built some distance to the west of the old one.

The parish of St. Magnus extended as far as the drawbridge on Old London Bridge, which, it will be remembered, had buildings upon it on both sides and in the centre down to the year 1760 .

It occurred to me that the records of this church might yield some interesting information about the booksellers who at one time and another carried on their business on Old London Bridge, and I was not disappointed.

25* II.

c C 


\section{$3^{86}$ THE CHURCH OF ST. MAGNUS}

The earliest churchwardens' account-book, that escaped the fire of 1666 , is that covering the period from $1638-1734$, a massive folio volume in excellent preservation, into which the churchwardens' annual statements were copied by a professional scrivener, who was paid for his labour. In one respect this custom had its drawbacksnamely, in too much uniformity; on the other hand, it resulted in the entries being set out clearly and in detail. If the churchwarden for the year happened to be a man of some position, his coatof-arms was tricked by the scribe in the initial letter of the heading at the beginning of the account. For the most part the items of receipt and expenditure are entered very fully, but this, of course, largely depended upon the churchwarden's conception of his duty. Thus under the receipts for burials the name of the person buried, and for whom a knell was tolled, is almost always given, with the position of his grave in the church.

Seeing at what a late date these accounts begin, it is useless to expect any mention of William Pickering, who was the earliest London Bridge bookseller of whom we have any record, or of his successors, Richard Ballard and Hugh Astley; but the opening page of the book yields a valuable note respecting the house in which they carried on their business. This was variously described as 'at Saint Magnus Corner,' or 'under Saint Magnus Church,' and was the shop occupied by John Tapp, bookseller, who died in $16_{3} 1$. There has always been some doubt as to whether this shop escaped the fire which destroyed the houses 
on the north-east side of the bridge in 1633 . These accounts clear the matter up once for all. Amongst the entries of rents received by the churchwarden in the year ending 25th March, 1639, is a sum of twenty shillings paid by Edward Bellamy for a shop which is described as 'late John Tapp's under St. Magnus Church wall.' Its position, then, is clearly defined. It faced the approach to the bridge from the north, and stood at the corner of Thames Street, and backed on to the church wall. Clearly, then, the fire of 1633 did not reach this shop, which appears annually in the accounts, described in exactly the same words, down to the great fire of 1666 . Edward Bellamy, who occupied it from 1631 till his death in 1656 , was not a bookseller.

In this same year $163_{3} 8-9$, amongst the payments made by the churchwardens is the following item:

Paid Mr. Hurlock staconer for worke done to the church Bible and for bossing the same . . . . x xjs.

This was evidently George Hurlock, the son of Joseph Hurlock, to whom his father's rights in certain nautical books were transferred by Elizabeth Hurlock, the widow, on 16th January, $1633 / 4$. Where he was living at that time is not clear, but immediately after Edward Bellamy's death in 1656 he took the shop late John Tapp's at St. Magnus' Church Corner.

George Hurluck was senior churchwarden of St. Magnus in the year $1660-6 \mathrm{r}$, and he continued to occupy these premises until he was burnt out in 1666 . He then built a shed on the same spot, 


\section{THE CHURCH OF ST. MAGNUS}

but died in 1668, and was buried in the middle aisle of the church on 3 rd September, the debris being cleared away on purpose to allow of his interment. It is a remarkable fact in the history of this church, that though it was entirely destroyed, nothing but a few fragments of wall remaining, burials continued to be made there during the whole time of its reconstruction.

George Hurlock's widow carried on the business and paid rent for the shed under the church wall for about eighteen months after his death, after which we hear no more of her or of the shed; but between 1670 and 1672 several books were published bearing the imprint, 'Printed for Benjamin Hurlock and are to be sold at his shop over against St. Magnus' Church on London Bridge near 'Thames Street.'

This was no doubt the person whose burial is recorded in the accounts of the year 1673 :

June $16 . \quad 1673$, Received for the buriall of Benjamin Hurlock in the middle ile ..... I3s. 4 d. And for the passing bell \& knell .... 3s. 4 d.

There is nothing to indicate his relationship to George Hurlock, and as he is not found paying rent to the church, his premises were evidently not those previously known as 'John 'Tapp's.'

In following out this history of the Hurlocks, I have passed over other entries of considerable interest, to which I must now return.

In I 644 the church recovered, through the court of Chancery, a sum of $£ 250$ left by a certain Samuel Pettey or Petty, citizen and stationer or 
London, a name not hitherto met with by any student of this subject.

In the accounts of the year $1666-67$, the name of Thomas Passinger, the well-known bookseller who lived at the sign of the Three Bibles on London Bridge, is first met with, the entry being for the burial of one of his children. This coincides very nearly with the date of the first publication bearing his imprint. In 1671 he is again referred to in another entry of the same character:

Augt 10. 1671, Received for the burial of a maid of Thomas Passinger in the Tabernacle . . . . 23.

and again on 6th March, 1673/4:

Received for the buriall of Mr. Passinger's man in the Tabernacle ..... 2 s.

Thomas Passinger found time to take an active part in parish work, and he served the office of churchwarden of St. Magnus in the year I 68 I-82.

The building which had arisen from the ashes of 1666 was still far from complete, and amongst the numerous payments made to workmen during Passinger's year of office, the following are worth recording:

Spent in buying a hogshead of wine to present to Sir Christopher Ren ...... 2s.

Spent about attending $\mathrm{S}^{\text {r. }}$ Christopher Ren about the steeple ......4.4s.

Spent more attending $\mathrm{S}^{\mathrm{r}}$. Christopher Ren about ye steeple ..... 2s. Id.

Paid Collins upon Sr. Christopher Ren's surveigh . . . ... $\ell_{3}$. 


\section{THE CHURCH OF ST. MAGNUS}

On I $5^{\text {th }}$ October, I683, the burial of $\mathrm{Mr}$. Charles Passinger in the south aisle of the church is recorded. He carried on the business of a bookseller at the Seven Stars in the New Buildings, and was clearly a relative of Thomas Passinger's, and this entry fixes the period of his occupation of these premises. In the same year the churchwardens

Pd. Mr. Passinger for a booke of Cannons 1s. 6d.

$\mathrm{Pd}$. Mr. Passinger for a common prayer book

these entries referring to Thomas Passinger. During the wardenship of Mr. Thomas Worley, combmaker, in I 684-5, Passinger's name frequently crops up in such entries as these :

July 15. Paid Mr. Passinger for a booke . 16s. od.

Sept . 3. Spent at ye Swanne tavern with Mr. Passinger and my partner . . 3s. rod.

Nov. 27. Spent with Mr. Passinger \& others about parish business - . 3s. $2 \mathrm{~d}$.

We already know that Thomas Passinger died in I 688, and the following entry in these accounts shews that he was buried in the Church of St. Magnus:

I 688. June $8^{\text {th }}$. Rec ${ }^{d}$ for the buriall of Mr. Thomas Passinger ..... Ł 5 5s. 8d.

His business was carried on for some time by his widow, and in the following year's accounts it is recorded:

1689. March 28. Paid Mrs Passinger for some parchment leaves putt into the register booke .... I8s. 
She died in 1692 , and was also buried in the south aisle of St. Magnus, and the business passed to her nephew, Thomas Passinger, who can be traced until 1695, when he was succeeded by Ebenezer Tracy.

During the next twenty years several entries are met with in these accounts concerning booksellers on the Bridge, confirming what is already known of their history, and in some instances throwing fresh light upon it. Here are some of them:

1703. July $3^{\text {rd }}$. $\operatorname{Rec}^{d}$ for the buriall of Mr. John Back in the cloyster ...... 9s. rod.

1703. Jan' 24. Rec for the buriall of a daughter of Mr. Tracey in the lower end of the South Ile ..... I6s. 6d.

I70 年. Jan ${ }^{y} 16^{\text {th }}$. $\operatorname{Rec}^{d}$ for the buriall of $M^{x}$. Blair's maid servant in the Churchyard Alley .....4.

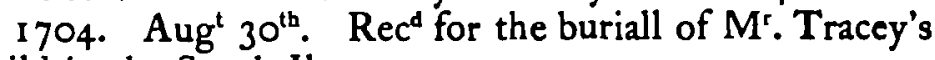
child in the South lle ..... I4s.

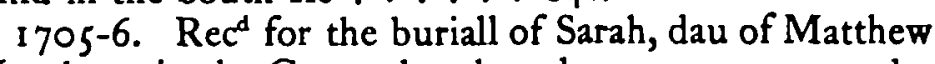
Hootham, in the Green churchyard ...... gs. Iod.

I 706-7. Rec for the buriall of $M^{r}$. Joseph Blare, in the new vault ..... £i I 5s. 8d.

1712-13. Paid sof irs. for $M^{r}$. Tracy's Common Prayer Book.

1714-15. Rec of $M^{r}$. Ebenezer Tracy for his fine for churchwarden only ..... 12 .

- $\operatorname{Rec}^{\mathrm{d}}$ for the buriall of $\mathrm{M}^{\mathrm{r}}$. Hothum's child in the great vault .....

- $\operatorname{Rec}^{d}$ for the buriall of $\mathbf{M}^{r}$. Blayer in the great vault ...... 35 s.

1717. June 8. $\operatorname{Rec}^{d}$ for the buriall of $M^{x}$. Tracey in the church ..... \&r os. Iod.

John Back, whose burial is recorded above, carried on business as a bookseller at the sign of the Black 


\section{THE CHURCH OF ST. MAGNUS}

Boy on London Bridge, near the drawbridge. He was succeeded by Matthew Hotham, Hootham or Hothum, who was also buried in St. Magnus in 1725 .

Joseph Blare, whose burial is recorded above in the accounts for the year 1706-7, is no doubt identical with Josiah Blare, the first tenant of the Looking Glass on London Bridge, whose will was

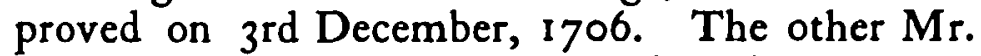
'Blayer,' buried in 1714 -1 5 , may have been his son Josiah, who was not of age at the time of his father's death; but why so large a sum should have been charged for his interment is a mystery. Nor is it clear who the Mr. 'Tracey' was who was buried on 8th June, 1717. It was certainly not Ebenezer Tracy, who was still at the Three Bibles in the year 1719 , as appears from an advertisement in the 'Weekly Journal' of $17^{\text {th }}$ January of that year. It is quite astonishing what an amount of bibliographical information is contained in the sheets that did duty for newspapers in the first half of the eighteenth century. We are apt to look upon them somewhat contemptuously as being too insignificant to contain anything worth notice. And again many students are deterred by the weariness of searching these sheets. But the result fully justifies the labour.

It is not generally known that there were two shops with the sign of the Three Bibles on London Bridge at the beginning of the eighteenth century. In the issue of the 'Post Boy' from Saturday, 2nd January, to Tuesday, 5th January, $17 \frac{13}{14}$ appeared the following advertisement : 


\section{AND THE BOOKSELLERS.}

John Stuart, stationer, at the 3 Bibles, the corner house of the square, about the middle of London Bridge, having a large quantity of fine playing cards, viz. Whiske, Basset, Pickit and Ombro, with divers other sorts, made by the best makers, sealed according to the late Act of Parliament continues still to sell at very reasonable rates (as many have already experienc'd) and gives as much encouragement to the buyer as any man. N.B. He has a variety or sorts of new figur'd paper for hanging of rooms, very cheap.

But not only did Stuart take the same sign, but he also dealt in a quack medicine to which he gave the same name as a similar medicine sold by Ebenezer Tracy and his successors, and called the Balsam of Chili.

In 1724 this called forth a vigorous protest from John Tracy, one of the firm of H. and J. Tracy, inserted in an edition of James Love's 'Mariner's Jewel,' which they issued in that year. In this he says:

All persons are desired to beware of a pretended Balsam of Chili, which for about this seven years past hath been sold and continues to be sold by Mr. John Stuart, at the Old Three Bibles, as he calls his sign, although mine was the sign of the Three Bibles twenty years before his.

This last statement seems to throw some doubt on the hitherto accepted belief that Ebenezer Tracy and his successors occupied the same shop as that which had previously been held by Charles Tyus and Thomas Passinger, and whose history began in 1656 . It is possible that Thomas Passinger's kinsman who succeeded to the business may have carried the sign to another house on the bridge, as 


\section{THE CHURCH OF ST. MAGNUS}

Ebenezer Tracy's career began about 1694 or '95, which would be just 'twenty years before.'

Later on John Stuart took into partnership Henry Woodgate, and the second volume of these churchwardens' accounts of St. Magnus, beginning in October, 1734, has pasted inside the cover the following printed ticket:

John Stuart and Henry Woodgate stationers at $y^{\circ}$ Three Bibles $y^{e}$ corner of ye square on London Bridge.

I think the preceding notes show that this firm were dealers in stationery rather than booksellers, and they probably continued to occupy these premises until the demolition of the houses on the bridge in $175^{\circ}$.

Two other eminent booksellers are met with in these churchwardens' accounts. In 1720 we read:

July II. Thomas Norris for a Bible for $\mathrm{W}^{\mathrm{m}}$. Magnus apprentice ..... 3s.

This refers to Thomas Norris, the bookseller, who succeeded Josiah Blare at the 'Looking Glass,' and it further illustrates a custom common in this as in other parishes of naming bastard children after the parish in which they were found. William Magnus was one of these unfortunates.

In the year 1 722-3 Thomas Norris was churchwarden of St. Magnus, and the following entries in his account are worth noting:

paid myselfe for a large Folio Bible for the church, very finely bound. Delivered $\operatorname{Dec}^{r} 24^{\text {th }} 1720 \ldots \ldots$. 66 i is. 3 d.

Paid ditto for five large common prayer, 4 for the churchwardens and I for the clerk, and new binding two old Bibles ...... Ł3 I3s. 9d. 
About the following year he appears to have retired from business and settled at Highgate, where he died in the year 1732, but as these churchwardens' accounts shew, he was buried in ground belonging to the united parish of St. Margaret, New Fish Street, on 6th June, 1732, and his will was proved in the Prerogative court of Canterbury on the following day (P.C.C. I74 Bedford).

Thomas Norris was succeeded at the Looking Glass by James Hodges, who also took an active part in the parish life of St. Magnus, to which he frequently supplied books, his yearly bill with the churchwardens amounting to between $£^{2}$ and $£ 3$.

$\mathrm{He}$ was churchwarden from Ladyday 1743 to Ladyday 1744 , but his account is a very short one, and with little or no detail. It has the appearance of an account kept by a very busy man in the midst of other duties. On I 7 th June, 1755, he signed the statement of accounts presented by the outgoing churchwarden, Mr. Robert Hale, this being the last time his name occurs in the book. Soon afterwards he also retired from business and was appointed Clerk to the City of London. In $175^{8}$ he became Sir James Hodges, being knighted on the occasion of presenting an address to the King. He died in 1774, but the place of his burial is not known.

Henry R. Plomer. 